\title{
PENGARUH KINERJA KUALITAS LAYANAN YANG DIRASAKAN DAN NILAI PELANGGAN TERHADAP PEMBELIAN ULANG (STUDI PADA BUSWAY TRANSJAKARTA)
}

\author{
Nazwirman \\ Program Studi Magister Manajemen Universitas YARSI Jakarta, Indonesia \\ e-mail: nazwirman@yarsi.ac.id
}

\begin{abstract}
The study was conducted on the Transjakarta busway. The purpose of the study was to analyze and determine the effect of perceived service quality variables and customer value variables on repurchase variables. The results of the study partially there is a significant positive effect on the perceived service quality on the variable repurchase. Partially there is a positive no significant effect on the Customer Value variable on the Repurchase variable. Simultaneously there is an effect of perceived service quality variables and Customer Value variables on Repurchase variables because in the F-count analysis> F-table. Based on the gender of female passengers on Busway trends. Marital status tends to be single. Age is predominantly between the ages of 20 and 30 years. Education level of most high schools. The most dominant jobs are private employees and the average passenger uses Transjakarta to work. The study uses descriptive associative method aims to determine the relationship between two or more variables.
\end{abstract}

Keywords: Transjakarta, perceived service quality, customer value, repurchase

\begin{abstract}
ABSTRAK
Penelitian dilakukan terhadap busway Transjakarta. Tujuan penelitian menganalisis dan mengetahui pengaruh variabel Kualitas Layanan yang dirasakan dan variabel Nilai Pelanggan terhadap variabel Pembelian Ulang. Hasil penelitian secara parsial terdapat pengaruh signifikan positif variabel Kualitas Layanan yang dirasakan terhadap variabel Pembelian Ulang. Secara parsial terdapat pengaruh tidak signifikan positif variabel Nilai Pelanggan terhadap variabel Pembelian Ulang. Secara simultan terdapat pengaruh variabel Kualitas Layanan yang dirasakan dan variabel Nilai Pelanggan terhadap variabel Pembelian Ulang karena dalam analisis $\mathrm{F}_{\text {-hitung }}>\mathrm{F}_{\text {-tabel. }}$. Berdasarkan jenis kelamin kecenderungan penumpang adalah perempuan. Status perkawinan kecenderungan berstatus single. Usia didominasi berusia antara 20 sampai dengan 30 tahun. Tingkat pendidikan sebagian besar SMU. Pekerjaan paling dominan karyawan swasta dan rata-rata penumpang menggunakan Transjakarta untuk bekerja. Penelitian menggunakan metode deskriptif asosiatif bertujuan untuk mengetahui hubungan antara dua variabel atau lebih.
\end{abstract}

Kata kunci: Transjakarta, kinerja kualitas layanan, nilai pelanggan, pembelian ulang

Meningkatnya kebutuhan transportasi Jakarta saat ini membuat Pemerintah Daerah Khusus Ibukota (DKI) Jakarta mencari cara untuk mengantisipasi kemacetan, salah satunya dengan menciptakan Busway Transjakarta. Busway Transjakarta memiliki jalur tersendiri dalam melintas 
sehingga tidak mengalami kemacetan karena tidak bersinggungan dengan kendaraan lain di jalan raya. Sebagai salah satu kota besar di dunia DKI Jakarta harus memiliki sistem transportasi yang maju, dengan mengutamakan pelayanan dan menciptakan nilai bagi pelanggan. Sistem dan jaringan transportasi antar moda belum seluruhnya terintegrasi dengan baik, sehingga menyebabkan mobilitas penduduk tidak efisien dan efektif. Sistem transportasi angkutan jalan raya tidak terhubung dengan baik dengan sistem dan jaringan transportasi berbasis rel. Begitu pula sistem dan jaringan angkutan bus massal (busway) belum terintegrasi dengan sistem angkutan feeder yang melayani permukiman masyarakat (https://bappeda.jakarta.go.id/uploads/.../2018.../63 Bab_4_RPJMD_DKI 20222.pdf, diunduh 18 Februari 2018). Resolusi pelayanan transportasi di Ibu Kota pada tahun 2017 ditargetkan mampu menembus 185 juta penumpang, naik 50 persen dari pencapaian tahun 2016 sejumlah 123,73 juta penumpang, kemudian meningkat 20 persen pada 2016 dari tahun 2015 yang mampu mencapai 102,95 juta. Hal itu beriringan dengan penambahan bus operasi di tahun 2015 sebanyak 605 unit dan di tahun 2016 itu 1.022 unit serta ditargetkan akhir tahun 2017 mencapai 3000 unit. Penambahan jumlah rute juga di 2015 ada 39 dan di 2016 menjadi 80. Berangkat dari pertumbuhan dan perkembangan yang ada tiap bulan sudah melayani sekitar 12 juta pelanggan. Tentunya, penambahan jumlah bus dan rute menjadi faktor penting untuk mencapai target tersebut. Bahkan, untuk tahun 2017 ini, Transjakarta menargetkan penambahan bus hingga terpenuhi sebanyak 3000 unit dari 2.590 unit yang sudah disiapkan (BeritaJakarta.Com). Selama Januari-Maret 2017, jumlah pengguna bus Transjakarta naik sebesar 41,3 persen dibanding periode yang sama tahun 2016. Bila pada triwulan pertama 2016 tercatat 25,99 juta penumpang, di triwulan pertama 2017 tercatat 36,68 juta penumpang. Saat ini Transjakarta telah melayani pelanggan rata-rata 450 ribu setiap hari kerja, sepanjang 2016 lalu Transjakarta sudah melayani 123,73 juta pelanggan. Jumlah ini naik 20,78 juta dibandingkan 2015 lalu yang hanya melayani 102,95 juta. Transjakarta mengoperasikan lebih dari 1.100 bus setiap harinya. Angka pengoperasian kendaraan tumbuh signifikan dibandingkan Januari 2016 lalu yang hanya 605 bus. Transjakarta telah memiliki lebih dari 1.500 bus pada kuartal pertama tahun ini. Jumlah ini akan terus bertambah hingga 3.000 pada akhir tahun 2017.

Saat ini organisasi bisnis ditantang untuk menarik pelanggan baru dan mengadopsi strategi untuk mempertahankan pelanggan dengan tujuan untuk membangun hubungan jangka panjang dengan pelanggan (Akbar, et al., 2013). Prinsip paling penting adalah bagaimana mempertahankan dan mencegah kehilangan pelanggan sehingga pangsa pasar dan profitabilitas perusahaan dapat terjamin (Osman et al., 2009; Yoo, 2008). Bisnis yang berulang merupakan hal penting bagi penyedia jasa untuk berhasil dengan mempertimbangkan keberhasilan dapat dilihat dari jumlah pelanggan yang berulang (Grewal et.al., 2004). Pelanggan yang menggunakan jasa kembali merupakan perihal yang kritis bagi kelangsungan sebuah perusahaan (Cho \& Rutherford, 2011).

Salah satu strategi pemasaran terpenting adalah memberikan nilai kepada pelanggan (Chen \& Hu, 2010). Menciptakan dan memberikan nilai pelanggan adalah sebagai dasar strategi pemasaran dalam bersaing (Berghman et al., 2006). Memahami nilai pelanggan adalah alat manajemen yang penting (Olaru et al., 2008). Dimana konsumen pada umumnya ingin mendapatkan nilai manfaat dari segi fungsional (functional benefit) maupun segi emosional (emotional benefit). Penciptaan nilai telah dilakukan dalam riset pemasaran (Heinonen, 2004).

Kualitas layanan dan nilai pelanggan adalah faktor yang paling penting bagi organisasi penyedia layanan. Kualitas layanan secara langsung berkaitan dengan niat pembelian kembali (Saleem et al., 2017). Keinginan membeli kembali merupakan salah satu niat pembelian konsumen yang memilih untuk menggunakan layanan dari perusahaan yang sama (William, 2002; McDougall \& 
Levesque, 2000). Keputusan konsumen yang berniat membeli kembali tergantung pada evaluasi kualitas layanan yang mereka terima (Liu \& Lee, 2016; Zhang et al., 2011; Kumar, 2002). Jika evaluasi kualitas layanan melebihi harapan konsumen, maka konsumen akan membeli kembali layanan, sebaliknya jika evaluasi kualitas layanan lebih rendah dari ekspektasi konsumen maka akan memberikan efek sebaliknya.

Perusahaan dapat mencapai keuntungan jangka panjang hanya melalui pembelian kembali (repurchase). Pembelian kembali adalah semacam perilaku berdasarkan pengakuan dan emosi (Aghazadeh et al., 2013), dan merupakan indikator perilaku pelanggan (Ha et al., 2010). Niat pembelian kembali adalah faktor yang berdampak pada hubungan masa depan pelanggan, organisasi, profitabilitas perusahaan dan keberhasilannya (Nikbin et al., 2011). Oleh karena itu, perusahaan harus terus berusaha mengambil langkah untuk memfasilitasi proses pembelian kembali. Dalam studi ini menguji kinerja kualitas layanan (Parasuraman, Zeithaml, dan Berry, 1990), nilai pelanggan (Monroe, 2005) terhadap Pembelian Ulang (Repurchase) (Molinari et al., 2008) pada penumpang Transjakarta.

\section{Kualitas Layanan yang Dirasakan (Perceived Service Quality)}

Kualitas layanan menjadi bidang perhatian bagi manajer, praktisi dan peneliti karena berdampak kuat pada kinerja bisnis (Nadiri, 2011). Kualitas layanan merupakan atribut yang ditentukan secara ekstrinsik oleh pelanggan (Walker et al., 2006). Kualitas layanan sebagai perbedaan antara harapan pelanggan tentang layanan yang dirasakan dan persepsi tentang layanan yang benar-benar diterima (Parasuraman et al., 1988; Gronroos, 1984). Asumsinya adalah untuk mengukur kualitas layanan sebagai perbedaan antara harapan dan persepsi (Wang et al., 2003). Alvani et al., (2009) menyebutkan kualitas layanan merupakan evaluasi pelanggan atas keuntungan keseluruhan atau keunggulan layanan atau persepsi umum konsumen tentang peringkat atau superioritas organisasi dari layanannya. Kualitas layanan muncul selama penawaran layanan dan mengirimkannya kepada pelanggan, yang mana layanan yang ditawarkan melampaui harapan mereka (Feiz, 2010).

Kualitas layanan ada lima dimensi (Parasuraman dan Zeithaml, 1988), sebagai berikut:

1. Jaminan: pengetahuan dan kesopanan karyawan dan kemampuan mereka untuk menciptakan jaminan (kombinasi dari dimensi utama dan aspek kompetensi, kesopanan, keandalan dan keamanan).

2. Empati: welas asih dan perhatian khusus yang diberikan perusahaan kepada pelanggan (meliputi aspek dan dimensi akses, membuat koneksi dan memahami pelanggan).

3. Keandalan: kemampuan untuk menawarkan layanan yang tepat dan tepercaya yang dijanjikan.

4. Daya tanggap: keinginan dan keinginan untuk membantu pelanggan dan menawarkan layanan dengan cepat.

5. Kasus nyata: penampilan alat dan peralatan, karyawan, dan instrumen komunikasi.

\section{Nilai Pelanggan (Customer Value)}

Ada dua karakteristik penting dalam nilai pelanggan (Roig et al., 2006). Pertama, nilai yang melekat pada penggunaan produk, yang membedakannya dari nilai-nilai pribadi atau organisasi. Kedua, yang dirasakan oleh pelanggan, dan tidak dapat ditentukan secara objektif oleh penjual. Hanya pelanggan yang dapat melihat apakah suatu produk atau layanan yang menawarkan nilai. Nilai pelanggan (customer value) merupakan persepsi pelanggan tentang keseimbangan antara manfaat yang diterima dengan pengorbanan yang diberikan untuk mendapatkan manfaat tersebut 
(Buttle, 2007). Woodall (2003) mendefinisikan nilai pelanggan (customer value) sebagai keseluruhan persepsi personal mengenai sebuah keuntungan yang akan didapat oleh pelanggan berkaitan dengan adanya penawaran dari suatu perusahaan, dan dapat dicapai dengan mengurangi pengorbanan atau memberikan manfaat seperti yang diinginkan oleh pelanggan. Dimensi customer value yang digunakan terdiri dari lima indikator (Woodall, 2003) yaitu:

1. Net value for the customer; dimana nilai pelanggan diperlihatkan pada saat pelanggan membuat penilaian mengenai kegunaan dari suatu produk atau layanan dengan menghitung atau membandingkan bobot atau kuantitas dari suatu manfaat dan pengorbanan.

2. Derived value for the customer; nilai pelanggan dikonsepkan sebagai suatu manfaat (benefit) yang diperoleh dari pengalaman konsumsi pelanggan.

3. Marketing value for the customer; nilai pelanggan dipahami sebagai atribut-atribut produk dan merupakan strategi yang penting terutama oleh perusahaan yang akan masuk ke pasar.

4. Sale value for the customer; nilai pelanggan dirasakan sebagai pengurangan pengorbanan atau harga yang terjangkau. Hal ini berarti harga yang terjangkau adalah harga yang relatif rendah dalam lingkungan yang kompetitif (pasar), dan dapat dipandang sebagai nilai pertukaran yang sesuai.

5. Rational value for the customer; Rational value for the customer adalah suatu bentuk nilai pelanggan yang mengkombinasikan nilai pertukaran (exchange value) dengan nilai intrinsik (intrinsic value). Bergantung dengan pertimbangan akan manfaat atau atribut yang diterima dari suatu produk, pelanggan akan menghitung harga yang adil terhadap harga yang tertera pada suatu produk.

\section{Pembelian Ulang (Repurchase)}

Bentuk spesifik dari minat pembelian adalah melakukan pembelian ulang atau yang mencerminkan harapan untuk membeli ulang baik produk atau merek yang sama (Engel, Blackwell dan Miniard, 2001). Jadi jika pelanggan merasakan minat untuk membeli ulang dari produk atau jasa yang sama, hal itu dikarenakan pelanggan tersebut merasa mendapatkan manfaat dari produk atau jasa tersebut.

Pembelian ulang merupakan suatu faktor dimana akan mempengaruhi hubungan antara pelanggan dan perusahaan di masa depan menyangkut keuntungan dan kesuksesan perusahaan (Nikbin et al., 2011). Penelitian ini dimensi pembelian ulang (repurchase) yang digunakan adalah dimensi berdasarkan Nikbin et al., (2011). Dimensi repurchase intentions yang digunakan diukur dengan tiga indikator, (1) Menggunakan kembali, (2) Pilihan utama untuk pembelian selanjutnya, dan (3) Ada niat yang kuat untuk mencoba jenis produk yang lain.

\section{Pengembangan Hipotesis}

Keinginan membeli kembali adalah salah satu pembelian dari konsumen yang memilih dan menggunakan layanan dari perusahaan yang sama (McDougall \& Levesque, 2000; William, 2002). Keputusan konsumen untuk membeli kembali tergantung pada evaluasi kualitas layanan yang mereka terima (Liu \& Lee, 2016; Zhang et al., 2011; Kumar, 2002). Jika evaluasi kualitas layanan melebihi harapan konsumen, maka konsumen akan membeli kembali layanan, sebaliknya jika evaluasi kualitas layanan lebih rendah dari ekspektasi konsumen maka akan memberikan efek sebaliknya. Minat membeli kembali merupakan faktor yang sangat penting bagi perusahaan jasa transportasi. Keputusan konsumen untuk tetap menggunakan layanan transportasi yang sama akan memberikan jaminan kepada perusahaan untuk keberlanjutan bisnis dan memastikan bahwa 
konsumen tidak beralih ke penyedia layanan lain. Berdasarkan analisis di atas, hipotesis penelitian yaitu:

$\mathrm{H}_{1}$ : Terdapat pengaruh signifikan Kualitas Layanan yang dirasakan terhadap Pembelian Ulang.

Nilai yang dirasakan konsumen sebagai penilaian keseluruhan terhadap kegunaan suatu layanan berdasarkan persepsi tentang apa yang diterima dan apa yang diberikan. Nilai yang dirasakan mewakili perbedaan antara manfaat yang dirasakan dan biaya yang dirasakan konsumen (Lee dan Cunningham, 2001). Nilai yang dirasakan pelanggan cenderung tinggi jika manfaat yang dirasakan lebih tinggi dari biaya yang dirasakan dan sebaliknya (Wen et al., 2005). Dalam studi transportasi umum, Lai \& Chen (2010) meneliti efek dari nilai yang dirasakan pada niat perilaku dalam layanan transportasi cepat masal. Hasil mereka mengungkapkan nilai yang dirasakan memiliki efek positif langsung pada niat perilaku. Berdasarkan teori, hipotesis penelitian yaitu:

$\mathrm{H}_{2}$ :Terdapat pengaruh signifikan Nilai Pelanggan terhadap Pembelian Ulang.

Po-Tsang Chen, (2009) mengeksplorasi hubungan antara atribut kualitas layanan dan nilai yang dirasakan dengan menggunakan lima dimensi kualitas layanan untuk mengukur kualitas layanan tetapi mereka berbeda dari SERQUAL. Dimensi-dimensi ini adalah persepsi layanan, kualitas, atmosfer, dan manfaat tambahan, di mana layanan yang dirasakan adalah yang paling penting dan manfaat tambahan yang paling tidak penting. Ismail, Abdullah, \& Francis, (2009) mempelajari hubungan antara kualitas layanan dan nilai yang dirasakan. Mereka hanya menggunakan tiga dimensi SERQUAL yaitu empati, jaminan dan daya tanggap untuk mengukur kualitas layanan. Studi ini menemukan bahwa hanya empati yang signifikan dengan nilai yang dirasakan untuk kepuasan pelanggan. Berdasarkan teori, hipotesis penelitian yaitu:

\section{$\mathrm{H}_{3}$ : Terdapat pengaruh bersama-sama Kualitas Layanan yang dirasakan dan Nilai Pelanggan terhadap Pembelian Ulang.}

Variabel yang teridentifikasi, dapat dibuat suatu konsep model antara Kinerja layanan yang dirasakan, Nilai Pelanggan terhadap Pembelian Ulang.

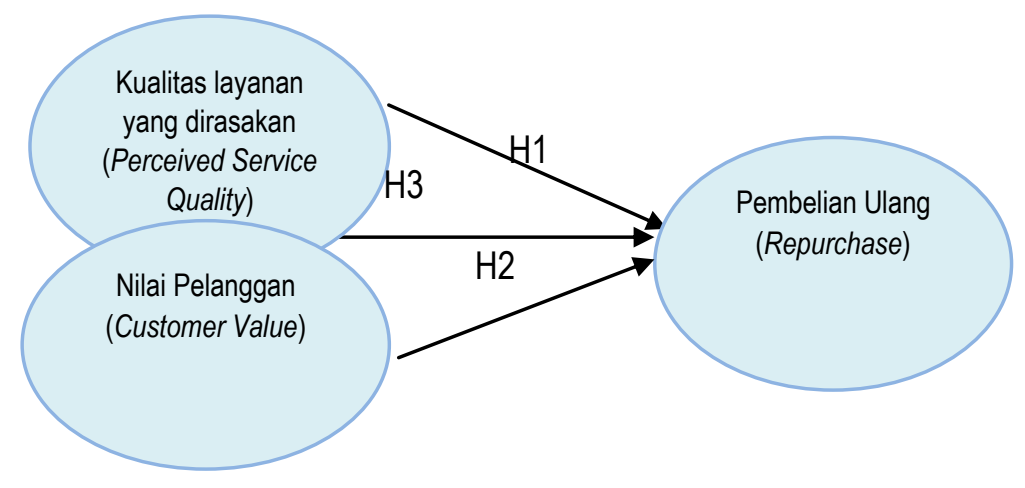

Gambar 1. Model Penelitian 


\section{METODE PENELITIAN}

Penelitian menggunakan metode deskriptif asosiatif. Penelitian yang bertujuan untuk mengetahui hubungan antara dua variabel atau lebih (Sugiyono, 2007). Sumber data barasal dari data primer yang digunakan adalah melalui kuesioner, wawancara, pengamatan kepada pengguna Busway Transjakarta serta diskusi dengan pihak-pihak tertentu yang akan ditetapkan berdasarkan hasil survei penelitian dan data sekunder dari jurnal, koran, majalah dan internet yang terkait dengan penelitian. Jawaban dari pertanyaan yang diajukan menggunakan Skala likert Sangat Setuju (SS) Bobot nilai 5 (lima) sampai Sangat Tidak Setuju (STS) Bobot nilai 1 (satu).

Sampel dalam penelitian ini adalah penumpang yang telah menggunakan Busway Transjakarta yang lebih dari lima kali. Peneliti menyebarkan sebanyak 210 responden berdasarkan jumlah indikator dikali 5 sampai 10 (Hair et al., 2010). Teknik pengambilan sampel dengan menggunakan teknik purposive sampling dimana sampel yang diambil dengan pertimbangan tertentu atau dipilih dengan menggunakan aturan-aturan tertentu (Sekaran \& Bougie, 2013; Sugiyono, 2010).

\section{Uji Validitas dan Uji Relibilitas}

Peneltian melakukan Uji Validitas, diperlukan untuk mengukur ketepatan item kuesioner yang digunakan untuk mengungkapkan sesuatu yang akan diukur (Sekaran \& Bougie, 2013). Rumus mengukur tingkat validitas menggunakan Pearson Product Moment. Jika $r$ hitung positif serta $r$ hitung $>r$ tabel, maka butir variabel tersebut valid atau sebaliknya variabel tersebut tidak valid ( $\left.r_{\text {hitung }}<r_{\text {table}}\right)$. Sedangkan uji reliabilitas untuk mengukur suatu kuesioner yang merupakan indikator dari variabel. Suatu kuesioner dikatakan reliabel (handal) jika jawaban terhadap pertanyaan konsisten atau stabil dari waktu ke waktu (Sekaran \& Bougie, 2013; Sugiyono, 2010). Pengukuran reliabilitas dilakukan dengan uji statistic nilai Cronbach Alpha (a). Suatu variabel dikatakan reliabel apabila nilai Cronbach Alpha > 0,70 (Sekaran, 2011).

\section{Regresi Linier Berganda}

Analisis digunakan untuk mengetahui besarnya pengaruh yang ada diantara Kinerja layanan yang dirasakan dan Nilai Pelanggan terhadap pembelian ulang secara bersama-sama. Analisis regresi linier berganda digunakan untuk mengetahui pengaruh satu atau lebih variabel bebas terhadap suatu variabel tak bebas (Sekaran \& Bougie, 2013; Sugiyono, 2010). Rumus yang digunakan dalam pengujian hipotesis regresi linier berganda, yaitu:

\section{Uji Hipotesis}

$$
Y=a+b_{1} \cdot X_{1}+b_{2} \cdot X_{2}
$$

Bertujuan untuk mengetahui apakah dapat menerima atau menolak hipotesis yang diajukan. Uji parsial (Uji t), untuk mengetahui besarnya pengaruh masing-masing variabel independen secara parsial terhadap variabel dependen (nila-nilai taraf signifikasinya sebesar $\alpha=5 \%$ ). Jika probabilitas (signifikansi) lebih besar dari 0,05 (a), maka variabel independen secara parsial tidak berpengaruh terhadap variabel dependen. Jika probabilitas (signifikansi) lebih kecil dari 0,05 (a), maka variabel independent secara parsial berpengaruh terhadap veriabel dependen (Sekaran, 2011). Jika sig F > 0,05 maka artinya tidak terdapat pengaruh yang signifikan antara variabel bebas dan variabel terikat.

\section{Uji Koefisien Determinasi $\left(\mathbf{R}^{2}\right)$}

Koefisien determinasi $\left(R^{2}\right)$ dimaksudkan untuk mengetahui tingkat ketepatan yang paling baik dalam analisa regresi, hal ini ditunjukkan oleh besarnya koefisien determinasi $\left(R^{2}\right)$ antara 0 (nol) 
sampai dengan 1 (satu). Jika koefisien determinasi nol, maka variabel independen tidak berpengaruh terhadap variabel dependen. Apabila koefisien determinasi semakin mendekati satu, maka dapat dikatakan bahwa variabel independen memberikan informasi yang dibutuhkan untuk memprediksi variasi variabel dependen atau variabel independen berpengaruh terhadap variabel dependen (Sekaran, 2011).

\section{HASIL DAN PEMBAHASAN}

Sesuai jumlah responden yang terkumpul yaitu sebanyak 200 (dua ratus) responden yang secara keseluruhan memenuhi kriteria yang telah ditetapkan sebelumnya dan layak untuk dilakukan analisis. Adapun hasil analisis deskriptif terbagi berdasarkan jenis kelamin, usia, pendidikan terakhir, status pekerjaan, penghasilan perbulan, dan keperluan menggunakan Busway Transjakarta (Tabel 1).

Tabel 1. Karakteritik Penumpang Busway Transjakarta

\begin{tabular}{|c|c|c|c|}
\hline \multicolumn{2}{|c|}{ Karekteristik } & Frek. & Persentase \\
\hline \multirow[t]{2}{*}{ Jenis Kelamin } & Laki-laki & 98 & 49 \\
\hline & Perempuan & 102 & 51 \\
\hline \multirow[t]{6}{*}{ Usia } & $<20$ tahun & 41 & 20,5 \\
\hline & $20-30$ tahun & 73 & 36,5 \\
\hline & $31-40$ tahun & 46 & 23 \\
\hline & $41-50$ tahun & 35 & 17,5 \\
\hline & $51-60$ tahun & 4 & 1,9 \\
\hline & Di atas 60 tahun & 1 & 0,5 \\
\hline \multirow[t]{5}{*}{ Pendidikan } & SMP & 17 & 8,5 \\
\hline & SMU & 100 & 50 \\
\hline & Akademi & 44 & 22 \\
\hline & Sarjana & 39 & 19,5 \\
\hline & Pascasarjana & 0 & 0 \\
\hline \multirow[t]{5}{*}{ Status Pekerjaan } & Karyawan Swasta & 98 & 49 \\
\hline & Pegawai Negeri Sipil & 20 & 10 \\
\hline & Wiraswasta & 27 & 13,5 \\
\hline & Pelajar/Mahasiswa & 5 & 26 \\
\hline & Pensiunan & 3 & 1,5 \\
\hline \multirow[t]{4}{*}{ Penghasilan Per bulan } & $<3 \mathrm{Jt}$ & 74 & 37 \\
\hline & $3-4,99 \mathrm{Jt}$ & 80 & 40 \\
\hline & $5-6 \mathrm{Jt}$ & 40 & 20 \\
\hline & $7-10 \mathrm{Jt}$ & 6 & 3 \\
\hline Keperluan Menggunakan Busway & Bekerja & 114 & 57 \\
\hline \multirow[t]{4}{*}{ Transjakarta } & Sekolah/Kuliah & 50 & 25 \\
\hline & Pariwisata & 6 & 3 \\
\hline & Lainnya & 30 & 15 \\
\hline & Jumlah & 200 & 100 \\
\hline
\end{tabular}

Berdasarkan jenis kelamin responden kecenderungan perempuan menggunakan tranportasi Busway. Berdasarkan status perkawinan kecenderungan menggunakan tranportasi Busway berstatus single. Berdasarkan usia didominasi oleh usia antara 20 sampai dengan 30 tahun. Berdasarkan tingkat pendidikan rata-rata pendidikan terakhir pengguna Busway Transjakarta SMU. Berdasarkan status pekerjaan, penumpang mendominasi karyawan swasta. Berdasarkan 
penghasilan perbulan antara 3 sampai 4,99 juta dan berdasarkan keperluan rata-rata penumpang menggunakan busway Transjakarta untuk bekerja.

\section{Uji Validitas dan Reliabilitas}

Nilai koefisien korelasi hasil uji validitas untuk variabel Kinerja Kualitas layanan yang dirasakan $\left(X_{1}\right)$, dari 15 (lima belas) indikator pertanyaan bahwa nilai $r_{\text {hitung }}>$ dari 0.138 ( $\left.r_{\text {tabel }}\right)$ sehingga variabel Kinerja Kualitas Pelayanan $\left(X_{1}\right)$ Valid. Nilai koefisien korelasi dari uji validitas untuk variabel Nilai Pelanggan $\left(X_{3}\right)$ dari 4 (empat) indikator pertanyaan, seluruh indikator variabel Nilai Pelanggan $\left(X_{2}\right)$ Valid ( $r_{\text {hitung }}>$ dari $0.138\left(r_{\text {tabel }}\right)$. Nilai koefisien korelasi dari uji validitas untuk variabel Pembelian Ulang (Y) dari 5 (lima) indikator pertanyaan, seluruh indikator variabel Pembelian Ulang $(\mathrm{Y})$ Valid $\left(\mathrm{r}_{\text {hitung }}>\right.$ dari $0.138\left(r_{\text {tabel }}\right)$.

Sedangkan hasil uji Reliabilitas seluruh variabel dinyatakan Reliabel, karena nilai Cronbach Alpha lebih besar dari 0.70 (Tabel 2).

Tabel 2. Reliability Statistics

\begin{tabular}{lccc}
\hline \multicolumn{1}{c}{ Variabel } & $\begin{array}{c}\text { Cronbach's } \\
\text { Alpha }\end{array}$ & Jumlah & Keterangan \\
\hline Kualitas Pelayanan yang dirasakan $\left(\mathrm{X}_{1}\right)$ & 0,951 & 15 & Reliabel \\
Nilai Pelanggan $\left(\mathrm{X}_{2}\right)$ & 0,855 & 4 & Reliabel \\
Pembelian Ulang/ Repurchase Intention $(\mathrm{Y})$ & 0,910 & 5 & Reliabel \\
\hline
\end{tabular}

\section{Analisis Regresi Linier Berganda}

Regresi linier berganda antara variabel Kinerja Kualitas Pelayanan yang dirasakan $\left(X_{1}\right)$, Variabel Nilai Pelanggan $\left(\mathrm{X}_{2}\right)$, dan Pembelian Ulang $(\mathrm{Y})$ (Tabel 3) yaitu:

Tabel 3. Regresi Linier Berganda

\begin{tabular}{|c|c|c|c|c|c|c|}
\hline & \multirow[t]{2}{*}{ Model } & \multicolumn{2}{|c|}{$\begin{array}{l}\text { Unstandardized } \\
\text { Coefficients }\end{array}$} & \multirow{2}{*}{$\begin{array}{c}\text { Standardized } \\
\text { Coefficients } \\
\text { Beta }\end{array}$} & \multirow[t]{2}{*}{$t$} & \multirow[t]{2}{*}{ Sig. } \\
\hline & & $B$ & Std. Error & & & \\
\hline \multirow[t]{3}{*}{1} & (Constant) & 1,705 & 1,078 & & 1,582 & 0,115 \\
\hline & $\begin{array}{l}\text { Kualitas Pelayanan yang dirasakan } \\
\text { (X1) }\end{array}$ & 0,319 & 0,013 & 0,904 & 25,342 & 0,000 \\
\hline & Nilai Pelanggan (X2) & 0,012 & 0,042 & 0,009 & 0,287 & 0,774 \\
\hline
\end{tabular}

a. Dependent Variable: Pembelian Ulang (Y)

Sumber: Hasil Penelitian yang Diolah, 2017

Dari hasil perhitungan analisis regresi berganda (Tabel 3) persamaanya yaitu:

$$
\hat{Y}=1,705+0,904 X_{1}+0,009 X_{2}+e
$$

Konstanta sebesar 1,705 menunjukkan pada kualitas layanan yang dirasakan dan nilai pelanggan akan tetap atau sebesar 1,705. Setiap terjadi peningkatan variabel kinerja kualitas layanan yang dirasakan berpengaruh terhadap peningkatan variabel pembelian ulang sebesar 0,319 
dengan asumsi variabel lainnya nilainya tetap. Setiap terjadi peningkatan variabel nilai pelanggan berpengaruh terhadap peningkatan variabel pembelian ulang sebesar 0,012 dengan asumsi variabel lainnya nilainya tetap.

\section{Pengaruh Kualitas Layanan yang dirasakan terhadap Pembelian Ulang.}

Dari hasil analisis parsial (uji t) pada pengujian koefisien regresi variabel kualitas kinerja layanan yang dirasakan $\left(X_{1}\right)$ dimana nilai thitung $>t_{\text {tabel }}$ yaitu 25,342 > 1,972 maka $\mathrm{H}_{0}$ ditolak, artinya bahwa kualitas kinerja pelayanan secara parsial berpengaruh terhadap pembelian ulang. Nilai thitung dengan nilai Sig. 0,000>0,05 berarti berpengaruh signifikan variabel kualitas kinerja pelayanan terhadap variabel pembelian ulang.

Kualitas layanan merupakan evaluasi menyeluruh oleh konsumen dari layanan yang disediakan oleh perusahaan (Zeithaml, 1988). (Nazwirman, 2015; Saha \& Theingi, 2009) menambahkan bahwa evaluasi kualitas layanan konsumen didasarkan pada apakah kualitas layanan yang mereka terima sesuai dengan harapan konsumen sebelum menerima layanan. Sedangkan pembelian kembali adalah salah satu pembelian yang dilakukan konsumen untuk memilih dan menggunakan layanan dari perusahaan yang sama (McDougall \& Levesque, 2000; William, 2002). Keputusan konsumen membeli kembali tergantung pada evaluasi kualitas layanan yang diterima (Liu \& Lee, 2016; Zhang et al., 2011; Kumar, 2002). Pembelian Kembali merupakan faktor yang sangat penting bagi perusahaan jasa transportasi. Keputusan konsumen untuk tetap menggunakan layanan transportasi yang sama akan memberikan jaminan kepada perusahaan untuk kelanjutan bisnis dan memastikan bahwa konsumen tidak beralih ke penyedia layanan lain.

\section{Pengaruh Nilai Pelanggan terhadap Pembelian Ulang.}

Dari hasil analisis parsial (Uji t), dimana nilai thitung $>t_{\text {tabel }}$ yaitu $0,287<1,972$ maka $\mathrm{H}_{0}$ diterima, artinya bahwa nilai pelanggan secara parsial tidak berpengaruh terhadap pembelian ulang . Nilai thitung Sig. 0,774 > 0,05, berarti tidak berpengaruh signifikan variabel Nilai Pelanggan terhadap variabel Pembelian Ulang.

Pengukuran penelitian ini disusun sesuai dengan definisi nilai sebagai trade-off antara komponen manfaat dan pengorbanan (Zeithaml, 1988). Nilai-nilai fungsional, emosional, dan sosial dianggap sebagai komponen manfaat, sementara biaya moneter, bersama dengan waktu dan biaya usaha diambil sebagai komponen pengorbanan. Nilai fungsional merupakan utilitas yang berasal dari kualitas yang dirasakan dan kinerja yang diharapkan dari layanan, dan diperoleh sebagai hasil dari kemampuan produk atau layanan untuk melakukan fungsinya. Nilai emosional digambarkan sebagai utilitas yang berasal dari perasaan atau pernyataan afektif yang dihasilkan produk atau layanan (Sweeney dan Soutar, 2001). Nilai sosial disini sebagai utilitas yang berasal dari kemampuan produk atau layanan untuk meningkatkan konsep-diri sosial. Biaya moneter digambarkan sebagai harga suatu produk atau layanan yang dikodekan oleh konsumen (Zeithaml, 1988). Akhirnya, waktu dan biaya usaha adalah sebagai biaya memperoleh produk atau layanan, yang termasuk waktu, pencarian, upaya atau biaya psikis (Zeithaml, 1988).

Beberapa penelitian menunjukkan bahwa variabel seperti nilai digunakan untuk mengidentifikasi faktor-faktor yang mempengaruhi perilaku konsumen (Albayrak, Caber dan Comen, 2016; Wang, 2014; Yang et al., 2014; Roig, Garcia dan Tena, 2009; Hansen, Samuelsen dan Silseth, 2008). Berbagai studi menentukan bahwa produk yang dirasakan atau kualitas layanan, menunjukkan efek positif pada pembelian kembali (Dedeoglu, Balikcioglu dan Kucukergin, 2015; Yang et al., 2014; Han dan Hwang, 2013; Shukla, 2010; Molinari, Abratt dan Dion, 2008; Gallarza 
dan Saura, 2006). Di sisi lain, diputuskan bahwa harga yang dirasakan, pengorbanan yang dirasakan atau pengorbanan non-moneter, dan risiko yang dirasakan memiliki efek negatif pembelian kembali, atau kesetiaan (Xu, Peak \& Prybutok, 2015; Chiu et al., 2014; Chaohui, Lin \& Qiaoyun, 2012; Kasyap \& Bojanic, 2000).

Nilai yang dirasakan sebagai penilaian keseluruhan konsumen terhadap kegunaan suatu layanan berdasarkan persepsi tentang apa yang diterima dan apa yang diberikan. Nilai yang dirasakan mewakili perbedaan antara manfaat yang dirasakan dan biaya yang dirasakan (Lee \& Cunningham, 2001). Nilai yang dirasakan cenderung tinggi jika manfaat yang dirasakan lebih tinggi dari biaya yang dirasakan dan sebaliknya (Wen et al., 2005). Dalam studi transportasi umum, Lai dan Chen (2010) meneliti efek dari nilai yang dirasakan pada niat perilaku dalam layanan transportasi. Meskipun demikian, hal ini menunjukkan bahwa faktor-faktor seperti nilai sosial, nilai emosional, nilai simbolis, nilai hedonis atau nilai kenikmatan memiliki efek positif pada pembelian (Bakirtas, Bakirtas dan Cetin, 2015; Roig, Garcia \& Tena, 2009; Pihlström \& Brush, 2008).

\section{Uji F/Simultan}

Uji F digunakan untuk mengetahui apakah dalam model regresi variabel Kualitas layanan yang dirasakan $\left(X_{1}\right)$ dan Nilai Pelanggan $\left(X_{2}\right)$, secara simultan berpengaruh signifikan terhadap variabel Pembelian Ulang $(Y)$. Untuk mengetahui derajat keberartian persamaan regresi, dilakukan uji $\mathrm{F}$ dan hasilnya dapat ditelaah (Tabel 4).

Tabel 4. Analisis Varians Regresi Linier

\begin{tabular}{rlrrrrr}
\hline \multicolumn{7}{c}{ ANOVA $^{a}$} \\
\hline 1 & Model & Sum of Squares & \multicolumn{1}{c}{ Df } & Mean Square & \multicolumn{1}{c}{ F } & Sig. \\
\hline 1 & Regression & 772,329 & 4 & 193,082 & 223,812 & $0,000^{\mathrm{b}}$ \\
& Residual & 168,226 & 195 & 0,863 & & \\
& Total & 940,555 & 199 & & & \\
\hline
\end{tabular}

a. Dependent Variable: Pembelian Ulang

b. Predictors: (Constant), Nilai Pelangga n(X2), Kualitas Layanan yang dirasakan (X1)

Sumber : Hasil penelitian yang diolah, (2017)

Nilai $F_{\text {hitung }} 223,812$, sedangkan harga kritis nilai $F_{\text {tabel }}$ pada Sebesar $95 \%(\alpha=0,05)$ sebesar 3,890. Dengan demikian $F_{\text {hitung }}>F_{\text {tabel, }}$, sehingga $\mathrm{H}_{0}$ ditolak dan $\mathrm{H}_{1}$ diterima. Hal ini menunjukkan bahwa secara bersama-sama Kualitas Layanan yang dirasakan $\left(X_{1}\right)$ dan Nilai Pelanggan $\left(\mathrm{X}_{2}\right)$, berpengaruh positif dan signifikan terhadap Pembelian Ulang $(\mathrm{Y})$.

\section{Analisis Koefisien Determinasi}

Analisis koefisien determinasi digunakan untuk mengetahui persentase sumbangan (share) Kualitas Pelayanan yang dirasakan $\left(X_{1}\right)$ dan Nilai Pelanggan $\left(X_{2}\right)$, secara simultan terhadap terhadap Pembelian Ulang (Y). 
Tabel 5. Nilai Koefisien Determinasi

\begin{tabular}{lcccc}
\hline \multicolumn{5}{c}{ Model Summary $^{b}$} \\
\hline Model & $\mathrm{R}$ & $R$ Square & Adjusted R Square & Std. Error of the Estimate \\
\hline 1 & $0,906^{\mathrm{a}}$ & 0,821 & 0,817 & 0,929 \\
\hline a. Predictors: (Constant), Kualitas Layanan yang dirasakan, Nilai Pelanggan & \\
b. Dependent Variable: Pembelian Ulang & & \\
\hline Sumber : Hasil penelitian yang diolah, 2017 &
\end{tabular}

Berdasarkan perhitungan (Tabel 4) diperoleh nilai $\left(r^{2}\right)$ sebesar 0,821 atau 82,1 persen variabilitas Pembelian Ulang terjadi disebabkan oleh Kualitas Kinerja Pelayanan $\left(X_{1}\right)$ dan Nilai Pelanggan $\left(X_{2}\right)$. Artinya pengaruh Kualitas Layanan yang dirasakan $\left(X_{1}\right)$ dan Nilai Pelanggan $\left(X_{2}\right)$ secara simultan terhadap Pembelian Ulang $(Y)$ pada penumpang Transjakarta adalah sebesar 82,9 persen, sedangkan sisanya sebesar 17,1 persen dipengaruhi oleh faktor lain seperti pengaruh masyarakat dan budaya, faktor demografis dan lainnya.

Pembelian kembali adalah proses pembelian produk atau layanan tertentu yang berulang kali dari toko (Hellier, 2003). Alasan terpentingnya adalah setelah pengalaman membeli, perusahaan dapat mempertahankan pelanggan sebelumnya dengan biaya pemasaran rendah, bukan menarik yang baru pelanggan (Ranjbarian et al., 2012). Kebaruan dan nilai yang diterimanya dapat berdampak pada pembelian kembali, iklan lisan, dan komitmen pelanggan.

Po-Tsang Chen, (2009) mengeksplorasi hubungan antara atribut kualitas layanan dan nilai yang dirasakan dengan menggunakan lima dimensi kualitas layanan untuk mengukur kualitas layanan tetapi mereka berbeda dari SERQUAL. Dimensi-dimensi ini adalah persepsi layanan, kualitas, atmosfer, dan manfaat tambahan, di mana layanan yang dirasakan adalah yang paling penting dan manfaat tambahan yang paling tidak penting. Ismail, Abdullah, \& Francis, (2009) mempelajari hubungan antara kualitas layanan yang dirasakan dan nilai. Baik kualitas layanan yang dirasakan dan nilai secara signifikan mempengaruhi pembelian pelanggan

\section{SIMPULAN}

Penelitian yang dilakukan menggunakan variabel Kinerja Kualitas layanan yang, variabel Nilai Pelanggan dan Pembelian Ulang pada penumpang Busway Transjakarta. Hasil analisis adanya pengaruh yang signifikan positif Variabel kinerja kualitas layanan yang dirasakan terhadap pembelian ulang, sehingga perlu dipertahankan bahkan ditingkatkan.

Variabel nilai pelanggan tidak berpengaruh signifikan terhadap pembelian ulang. Namun nilai pelanggan memiliki peranan yang lebih kecil dalam terbentuknya pembelian ulang, sehingga diperlukan cara untuk terus melakukan perbaikan-perbaikan untuk meningkatkan nilai pelanggan yang berdampak pada peningkatan pembelian ulang. Dalam aspek yang lebih luas variabel kinerja kualitas layanan yang dirasakan dan nilai pelanggan secara simultan berpengaruh terhadap variabel pembelian ulang secara signifikan.

\section{REFERENSI}

Aghazadeh Hashem, Gholipour, Rahmatollah, Bakhshizadeh Elaheh. (2013). Investigating the Impact of Brand Personality on Repurchasing Intention through Perceived Value and Brand Loyalty (Case Study: Life Insured People of Saman Insurance Company). Scientific Research Quarterly Journal of New Marketing Research, 4(11), 1-22. 
Akbar, Ali Esmaeli, Baran Aryee Manesh, Ebrahim Golshan. (2013). Service Quality, Customer Satisfaction and Customer Loyalty in RAJA Rail Transportation Company. International Research Journal of Applied and Basic Sciences, 5 (3): 347-352.

Albayrak, T., Caber, M., \& Comen, N. (2016). Tourist Shopping: The Relationship Among Shopping Attributes, Shopping Value, and Behavioral Intention. Tourism Management Perspectives, 18, 98-106.

Alvani, Sayed Mahdi, Moghimi, Sayed Mohammad, Hafizi, Rohollah, Hamidizadeh, Ali. (2009). Assessment and Comparison of Service Quality in the Branches of Bank Melli of the City of Isfahan by Using Systemic Exchange Scale of Banking Service Quality (SYSTRA-SQ), Organizational Culture Management, Seventh Year, 20, Autumn and Winter 2009, 5-27.

Bakirtas, H., Bakirtas, I., \& Çetin, M. A. (2015). Effects of Utilitarian and Hedonic Shopping Value and Consumer Satisfaction on Consumer Behavioral Intentions. Ege Akademik Bakis, 15(1), 91-98.

Berghman, L., Matthyssens P. \& Vandenbempt, K. (2006). Building competences for new customer value creation: An exploratory study. Industrial Marketing Management, 35(8), 961-973.

Buttle, F. (2007). Customer Relationship Management: Terjemahan Arief Subiyanto. Jakarta: Bayumedia.

Chaohui, W., Lin, L. \& Qiaoyun, X. (2012). "Impact of tourists' perceived value on behavioral intention for mega events: Analysis of inbound and domestic tourists at Shanghai World Expo", Chinese Geographical Science, 22(6), 742-754.

Chen P.T., \& Hu H.H., (2010). How determinant attributes of service quality influence customer perceived value. International Journal of Contemporary Hospitality Management, 22(4): 535-51.

Chiu, C. M., Wang, E. T. G., Fang, Y. H. \& Huang, H. Y. (2014). Understanding customers' repeat purchase intentions in $\mathrm{B} 2 \mathrm{C}$ e-commerce: The roles of utilitarian value, hedonic value and perceived risk. Information Systems Journal, 24(1) 85-114.

Cho, Yoon-Na \& Brian N. Rutherford. (2011). Customers' Relationship with the Service Firm and Its Sales Personnel: Does Gender Matter? Journal of Marketing Theory and Practice 19(3), 325-36.

Dedeoglu, B. B., Balikcioglu, S. \& Kucukergin, K. G. (2015). The role of tourists' value perceptions in behavioral intentions: The moderating effect of gender". Journal of Travel \& Tourism Marketing, 33(4), 513-534.

Engel, J.F., Blackwell, R.D., Miniard, P.W. (2001). Consumen behavior (9th Ed). Orlando: Harcourt, Inc.

Feiz, Mohammad. (2010). Evaluating Service Quality of Bank Melli by Using SERVQUAL Method in Customers' Viewpoint Using Electronic Banking Services (Case Study: Bank Melli of the City of Yazd). Mater Thesis of the Accounting Course, Islamic Azad University, Yazd Branch.

Gallarza, M. G. \& Saura, I. G. (2006). Value dimensions, perceived value, satisfaction and loyalty: an investigation of university students' travel behavior, Tourism Management, 27(3), 437-452.

Grewal, D., Levy, M. \& Lehmann D. R. (2004.). Retail Branding and Customer Loyalty: An Overview'. Journal of Retailing, 80(4), 9-12.

Gronroos, C. (1984) A Service Quality Model and Its Marketing Implications. European Journal of Marketing, 18, 36-44. 
Ha, H.Y., Janda, S. \& Muthaly, S. S. (2010). A new understanding of satisfaction model in e-repurchase situation. European Journal of Marketing, 44 (7/8), 997-1016.

Hair, J., W. Black, B. Babin, \& R. Anderson. (2010). Multivariate data analysis, $7^{\text {th }}$ ed., Prentice Hall.

Han, H. \& Hwang, J. (2013). Multi-dimensions of the perceived benefits in a medical hotel and their roles in international travelers' decision-making process. International Journal of Hospitality Management, 35(1), 100-108.

Hansen, H., Samuelsen, B. M. \& Silseth, P. R. (2008). Customer perceived value in B-t-B service relations: Investigating the importance of corporate reputation, Industrial Marketing Management, 37, 206-2017.

Heinonen, K., Strandvik, T., and Voima, P. (2013). Customer dominant value formation in Service. European Business Review, 25 (2), 104-123.

Hellier, P.K., Geursen, G. M., Carr, R. A., \& Rickard, J. A. (2003). Customer Repurchase Intention : A General Structural Equation Model. European Journal of Marketing, 37(11), 1762-1800.

http://jakarta.bisnis.com/read/20170818/77/682078/jumlah-penumpang-transjakarta-naik (diunduh 18 Februari 2018).

https://bappeda.jakarta.go.id/uploads/.../2018.../63 Bab_4_RPJMD_DKI_20222.pdf (diunduh 18 Februari 2018).

Ismail, A., Abdullah, M. M., \& Francis, S. K. (2009). Exploring the relationships among service quality features,perceived value and customer satisfaction. Journal of industrial Engineering and Management , 2 (1), 230-250.

Kasyap, Rajiv K \& Davis C. Bojanic. (2000). A Structural analysis of value , and price perception of business and leisure travelers. Journal of Travel Research, 39(1), 45-51.

Kumar, P. (2002). The impact of performance, cost, and competitive considerations on the relationship between satisfaction and repurchase intent in business markets. Journal of Service Research, 5(1), 55-68.

Lai, W. T.; Chen, C. F. (2010). Behavioral intentions of public transit passenger - the role of service quality, perceived value, satisfaction and involvement. J.Transport Policy. 8(2), 318-325.

Lee, M.; Cunningham, L. F. (2001). A cost/benefit approach to understanding service loyalty. Journal of Services Marketing, 15(2), 113-130.

Liu, C. H. S., \& Lee, T. (2016). Service quality and price perception of service: Influence on word-ofmouth and revisit intention. Journal of Air Transport Management, 52, 42-54.

McDougall, G. H., \& Levesque, T. (2000). Customer satisfaction with services: putting perceived value into the equation. Journal of services marketing, 14(5), 392-410.

Molinari, L. K., Abratt, R.\& Dion, P. (2008). Satisfaction, quality and value and effects on repurchase and positive word-of-mouth behavioral intentions in a B2B services context, Journal of Services Marketing, 22(5), 363-373.

Monroe, Kent. B. (2005). Pricing: Making Profitable Decisions. 3nd Edition. New York: Mac Milan Nadiri H. (2011). Customers' zone of tolerance for retail store. Service Business, 5(2), 113-137. Nazwirman. (2015). The Influence of Perceived Service Performance and Price Fairness toward Repurchase through Customer Satisfaction and Word of Mouth, An Empirical Study of Lion Air Company. International Journal of Advanced Research, 3(10), 1846-1854.

Nikbin, D., Ismail, I., Marimuthu, M., \& Younis Abu-Jarad, I. (2011). The impact of firm reputation on customers' responses to service failure: the role of failure attributions. Business Strategy Series, 12(1), 19-29. 
Olaru D., Purchase S., \& Peterson N. (2008). From customer value to repurchase intentions and recommendations. Journal of Business \& Industrial Marketing, 23(8): 554-65.

Osman $\mathrm{H}$, Hemmington N, Bowie D. 2009. A transactional approach to customer loyalty in the hotel industy. International Journal of Contemporary Hospitality Management, 21(3):239250.

Parasuraman A, Valarie A. Zeithmal, Leornard L. Berry. (1990). Delivering Quality Service: Balancing Customer Perception and Expectations. (The Free Press). Serrvice environment. Services Marketing Quarterly. 31, 466-484.

Parasuraman, A., Berry, Leonard L., dan Zeithaml, Valarie A. (1988). A Concepttual Model of Service Quality and Its Implication for Future Research. Journal of Marketing, 41-50.

Pihlström, M., G.J. Brush. (2008). Comparing the perceived value of information and entertainment mobile services. Psychology \& Marketing. 25 (8), 732-755.

Po-Tsang Chen, H.-H. H. (2009). How determinant attributes of service quality influence customer perceived value: An empirical investigation of the Australian coffee outlet industry.

Ranjbarian Bahram, Rashidkaboli Kenari Majid, Sanayeie, Ali, and Hadadian Alireza. (2012). "Analysis of the Relationship Between Perceived value, Perceived Quality, Customer's satisfaction, and Repurchasing Intention in Chain Stores of Tehran". Quarterly of Business Management, 4(11), 55-70.

Roig J.C.F. et al., (2006). Customer perceived value in banking services. International Journal of Bank Marketing, 24(5), 266-83.

Roig, J. C. F., Garcia, J. S. \& Tena, M. A. M. 2009, "Perceived value and customer loyalty in financial services". The Service Industries Journal, 29(6), 775-789.

Saha, G. C., \& Theingi. (2009). Service quality, satisfaction, and behavioural intentions: A study of low-cost airline carriers in Thailand. Managing Service Quality: An International Journal, 19(3), 350-372.

Saleem, MA, Sadaf Zahra, Asif Yaseen. (2017). Impact of service quality and trust on repurchase intentions - the case of Pakistan airline industry. Asia Pacific Journal of Marketing and Logistics, 29(5), 1136-1159.

Sekaran, U., \& Bougie, R. (2013). Research Methods for Business. United Kingdom John Wiley \& Sons Ltd.

Shukla, P. (2010). Effects of perceived sacrifice, quality, value, and satisfaction on behavioral intentions in the service environment. Services Marketing Quarterly. 31(4), 466-484.

Sugiyono. (2010). Metode Penelitian Kuantitatif, Kualitatif dan R \& D. Bandung : Alfabeta.

Sweeney, J. C., \& Soutar, G. N. (2001). Consumer Perceived Value: The. Development of a Multiple Item Scale. Journal of Retailing, 77(2), 203-220.

Walker R.H., Johnson L.W., \& Leonard S. (2006). Re-thinking the conceptualization of customer value and service quality within the service-profit chain. Managing Service Quality, 16(1): 23-36.

Wang, E. S. T. (2014). Do farmers' market and specialty food store customers differ in the effects of perceived utilitarian and hedonic shopping values?, Journal of Marketing Channels, 21(2), 77-86,

Wang, Y., Lo, H. \& Hui, Y.V. (2003). The antecedents of service quality and product quality and their influences on bank reputation: evidence from banking industry in China, Managing Service Quality, 13(1), 72-83. 
Wen, C. H.; Lawrence, W. L.; Cheng, H. L. (2005). Structural equation modeling to determine passenger loyalty toward intercity bus services, Journal of the transportation research board, 1927: 249-255.

William, Auchil. (2002). Relationship Marketing Delivering Customer Satisfaction, Oxford: ButterWorth-Heinemann.

Woodall, T. (2003). Conceptualising 'value for the customer': an attributional, structural and dispositional analysis. Academy of Marketing science Review, 12(1), 1-42.

Xu, C., Peak, D. \& Prybutok, V. (2015). A customer value, satisfaction, and loyalty perspective of mobile application recommendations", Decision Support Systems, 79, 171-183.

Yang, Y., Liu, X. Jing, F. \& Li, J. (2014). How does perceived value affect travelers' satisfaction and loyalty?, Social Behavior And Personality. 42(10), 1733-1744.

Yoo B. (2008). Cross-national invariance of the effect of personal collectivistic orientation on brand loyalty and equity. Asia Pacific Journal of Marketing and Logistics, 21(1):41-57.

Zeithaml, V. A. (1988). Consumer perceptions of price, quality, and value: a means-end model and synthesis of evidence. The Journal of marketing, 52(3),2-22.

Zhang, Y., Fang, Y., Wei, K. K., Ramsey, E., McCole, P., \& Chen, H. (2011). Repurchase intention in B2C e-commerce-A relationship quality perspective. Information \& Management, 48(6), 192-200. 